\title{
Nocardiopsis arvandica sp. nov., isolated from sandy soil
}

\author{
Javad Hamedi, ${ }^{1}$ Fatemeh Mohammadipanah, ${ }^{1}$ Gabriele Pötter, ${ }^{2}$ \\ Cathrin Spröer, ${ }^{2}$ Peter Schumann, ${ }^{2}$ Markus Göker ${ }^{2}$ and \\ Hans-Peter Klenk ${ }^{2}$ \\ ${ }^{1}$ Microbial Biotechnology Laboratory, Department of Microbiology, School of Biology, College of \\ Science, University of Tehran, 14155-6455, Tehran, Iran \\ ${ }^{2}$ DSMZ - German Collection of Microorganisms and Cell Cultures GmbH, Inhoffenstraße 7B, \\ 38124 Braunschweig, Germany
}

Correspondence Javad Hamedi jhamedi@ut.ac.ir
Members of the genus Nocardiopsis are mesophilic, aerobic actinomycetes that produce arthrospores on aerial mycelia. At the time of writing, the genus Nocardiopsis harboured 29 recognized species. The natural habitat of most recognized members of the genus is soil (Kroppenstedt \& Evtushenko, 2002). Species of the genus Nocardiopsis have also been found in an Antarctic glacier, in marine sediments, in the actinorhizal plant rhizosphere, in the gastrointestinal tract of animals, as endophytes of yam bean, in salterns and in clinical material. Nearly all recognized species of the genus Nocardiopsis have, up until now, been found at sites of moderate temperatures. Thermotolerant strains, which are able to grow at temperatures of up to $42{ }^{\circ} \mathrm{C}$ or even at $50{ }^{\circ} \mathrm{C}$, have their optimal growth temperature at $28{ }^{\circ} \mathrm{C}$ (Evtushenko et al., 2000) or, in the case of Nocardiopsis kunsanensis, at $37{ }^{\circ} \mathrm{C}$ (Chun et al., 2000). Members of this genus frequently have been isolated from areas with high salt concentrations, such as Nocardiopsis lucentensis from a

The GenBank/EMBL/DDBJ accession number for the $16 \mathrm{~S}$ rRNA gene sequence of strain UTMC $00103^{\top}$ is EU410477.

Supplementary figures are available with the online version of this paper. salt marsh soil, a Nocardiopsis halotolerans strain from the same environment, Nocardiopsis halophila from a saline soil and N. kunsanensis from a saltern. Mildly alkaline conditions $(\mathrm{pH} 8)$ are best for optimal growth of most strains of this genus. For some species, i.e. Nocardiopsis prasina and Nocardiopsis dassonvillei subsp. albirubida, growth is enhanced at even higher $\mathrm{pH}$ values. Generally, many of the species of the genus Nocardiopsis prefer moderately alkaline conditions ( $\mathrm{pH} 8.5$ ) (Kroppenstedt, 1992) and some grow better on media supplemented with sodium chloride. Therefore, Nocardiopsis strains are frequently isolated from alkaline soils with high salt concentrations (Mikami et al., 1982; Yassin et al., 1993).

In this paper, the taxonomic characterization and classification of strain $\mathrm{HM}^{\mathrm{T}}$, an isolate from sandy soil, is reported and a novel species in the genus Nocardiopsis is proposed.

Strain $\mathrm{HM}^{\mathrm{T}}$ was isolated from a soil sample collected from sandy soil ( $\mathrm{pH} 8.7$, salinity $2.6 \%$ ) taken at a depth of $10 \mathrm{~cm}$ on the right bank of the Arvand River in Khoramshahr city, Khuzestan province, Iran. The soil 
Table 1. Cultural characteristics of strain $\mathrm{HM} 7^{\top}$

Colours were taken from ISCC-NBS colour charts (Kelly, 1964).

\begin{tabular}{|lccc|}
\hline Medium $^{\star}$ & Growth & Aerial mycelium & Substrate mycelium \\
\hline Yeast extract-malt extract (ISP 2) & Good & Light brown & Light brown \\
Oatmeal agar (ISP 3) & Relatively poor & White & Pale yellow \\
Inorganic salts-starch agar (ISP 4) & Poor & Light yellow & Light yellow \\
Glycerol-asparagine agar (ISP 5) & Very poor & Pale brown & Pale brown \\
\hline
\end{tabular}

${ }^{\star}$ ISP, International Streptomyces Project (Shirling \& Gottlieb, 1966).

sample was dried (Nolan \& Cross, 1988), oven-dried at $120{ }^{\circ} \mathrm{C}$ for $10 \mathrm{~min}$ (Nonomura \& Ohara, 1971) and then irradiated at $257 \mathrm{~nm}$ for $10 \mathrm{~min}$ (Galatenko \& Terekhova, 1990). Soil samples were then treated with a phosphate buffer-soil extract solution (Hayakawa et al., 2000) and chlorhexidine gluconate (Hayakawa et al., 1991). Strains were isolated by a dilution plating method on AV agar (Nonomura \& Ohara, 1969) supplemented with cycloheximide $\left(100 \mu \mathrm{g} \mathrm{ml}^{-1}\right)$ after 21 days incubation at $28{ }^{\circ} \mathrm{C}$. Strains were maintained on ISP 2 agar slants at $4{ }^{\circ} \mathrm{C}$ and as $20 \%(\mathrm{w} / \mathrm{v})$ glycerol suspensions at $-20{ }^{\circ} \mathrm{C}$.

Cultural characteristics as well as soluble pigments were studied on ISP media as described by Shirling \& Gottlieb (1966). The colours of both substrate and aerial mycelia were determined by comparison with chips from ISCCNBS colour charts (Kelly, 1964) and soluble pigment production was determined.

The novel isolate was cultivated on ISP 2 agar for 14 days at $28{ }^{\circ} \mathrm{C}$ and cells were used for microscopic observations of sporophores, spore chains and the spore surface by using a light microscope with a coverslip technique (Kawato \& Shinobu, 1959) and a scanning electron microscope (CEM902A; Zeiss).

The colour of the aerial mycelium varied from white to pale brown on ISP media. The substrate mycelium was light yellow to pale brown. No soluble pigments were released on any medium (Table 1). Vegetative hyphae of strain $\mathrm{HM}^{\mathrm{T}}$ were long, well-developed and fragmented. Long spore chains were borne on the aerial hyphae. Strain $\mathrm{HM}^{\mathrm{T}}$ showed the typical microscopic appearance of most species of the genus Nocardiopsis (Meyer, 1994). Spores were rod-shaped $(0.4 \times 1.5 \mu \mathrm{m})$ and smooth-surfaced (see Supplementary Fig. S1 in IJSEM Online).

Carbon source utilization was tested on ISP 9 as a basal medium supplemented with a final concentration of $1 \%$ carbon source and $0.1 \%$ organic acid source (Shirling \& Gottlieb, 1966). Utilization of nitrogen sources, growth on other organic compounds, degradation activity and enzymic activity were determined as described by Williams et al. (1983).

The temperature range for growth of strain $\mathrm{HM}^{\mathrm{T}}$ was 15 $45{ }^{\circ} \mathrm{C}$, with optimum growth at $25-30{ }^{\circ} \mathrm{C}$. The strain showed good growth at $\mathrm{NaCl}$ concentrations up to $17.5 \%$, but was not able to grow in the presence of $20 \% \mathrm{NaCl}$. Strain $\mathrm{HM}^{\mathrm{T}}$ could grow well at $\mathrm{pH} 5-12$, but could not grow at $\mathrm{pH} 4$ or 13 .

For chemotaxonomic and molecular studies, strain $\mathrm{HM}^{\mathrm{T}}$ was cultured in GYM broth medium (Shirling \& Gottlieb, 1966) and incubated at $28{ }^{\circ} \mathrm{C}$ for 6 days at 200 r.p.m. Mycelia were harvested by centrifugation and washed twice with deionized water. Amino acid and sugar analyses of whole-cell hydrolysates were performed as described by Staneck \& Roberts (1974). Menaquinones and phospholipids were extracted by the integrated method of Minnikin

Table 2. Cellular fatty acid composition (\%) of strain $\mathrm{HM}^{\top}$ and closely related members of the genus Nocardiopsis

Strains: $1, \mathrm{HM}^{\mathrm{T}} ; 2$, N. sinuspersici DSM $45277^{\mathrm{T}} ; 3$, N. quinghaiensis DSM $44739^{\mathrm{T}} ; 4$, N. aegyptia DSM $44442^{\mathrm{T}} ; 5, N$. halotolerans DSM $44410^{\mathrm{T}}$. - , Not detected; ND, not reported.

\begin{tabular}{|c|c|c|c|c|c|}
\hline Fatty acids & 1 & 2 & 3 & 4 & 5 \\
\hline iso- $\mathrm{C}_{12: 0}$ & 0.2 & ND & $\mathrm{ND}$ & $\mathrm{ND}$ & $\mathrm{ND}$ \\
\hline iso- $\mathrm{C}_{13: 0}$ & 0.5 & $\mathrm{ND}$ & $\mathrm{ND}$ & $\mathrm{ND}$ & $\mathrm{ND}$ \\
\hline anteiso- $\mathrm{C}_{13: 0}$ & 0.8 & ND & $\mathrm{ND}$ & $\mathrm{ND}$ & $\mathrm{ND}$ \\
\hline iso- $\mathrm{C}_{14: 0}$ & 3.1 & 2.5 & 5.6 & 12.1 & 2.4 \\
\hline iso- $\mathrm{C}_{15: 0}$ & 1.5 & 0.7 & 2.6 & 1.7 & 3.4 \\
\hline anteiso- $\mathrm{C}_{15: 0}$ & 13.4 & 6.7 & 14.6 & 6.5 & 16.7 \\
\hline iso- $\mathrm{C}_{16: 0}$ & 22.8 & 31.1 & 30.0 & 19.1 & 23.3 \\
\hline $\mathrm{C}_{16: 0}$ & 2.2 & 0.6 & 3.7 & 4.2 & 3.2 \\
\hline $\mathrm{C}_{16: 1}$ & 0.3 & 0.3 & ND & 1.10 & 1.0 \\
\hline 10-methyl- $\mathrm{C}_{16: 0}$ & 0.6 & 0.7 & 1.8 & 1.5 & - \\
\hline $\mathrm{C}_{16: 1}$ & 1.7 & 0.3 & - & 1.1 & 1.3 \\
\hline iso- $\mathrm{C}_{17: 0}$ & 2.4 & 2.1 & 2.2 & 5.1 & 4.2 \\
\hline anteiso- $\mathrm{C}_{17: 0}$ & 19.2 & 19.2 & 10.0 & 17.9 & 18.7 \\
\hline $\mathrm{C}_{17: 0}$ & 4.6 & 2.0 & 2.8 & 1.3 & 3.1 \\
\hline $\mathrm{C}_{17: 1}$ & 2.4 & 1.6 & 2.7 & 1.7 & 6.8 \\
\hline anteiso- $\mathrm{C}_{17: 1}$ & 0.4 & 0.4 & - & 1.4 & - \\
\hline 10 -methyl- $\mathrm{C}_{17: 0}$ & 3.3 & 5.8 & 2.8 & 2.6 & 6.6 \\
\hline iso- $\mathrm{C}_{18: 0}$ & 2.7 & 4.2 & 1.4 & 3.2 & 1.3 \\
\hline $\mathrm{C}_{18: 0}$ & 8.8 & 6.0 & 4.5 & 7.3 & 3.5 \\
\hline $\mathrm{C}_{18: 1}$ & 3.3 & 3.3 & 4.6 & 7.8 & 8.5 \\
\hline 10-methyl- $\mathrm{C}_{18: 0}$ & 5.5 & 8.8 & 4.5 & 12.2 & 1.3 \\
\hline anteiso- $\mathrm{C}_{19: 0}$ & 0.8 & ND & ND & ND & $\mathrm{ND}$ \\
\hline
\end{tabular}


et al. (1984). The resultant phospholipids were separated and identified as described by Minnikin et al. (1984). The purified menaquinones were analysed by using HPLC (Kroppenstedt, 1982, 1985). Cellular fatty acid methyl esters were prepared and analysed according to the method of Sasser (1990).

Strain $\mathrm{HM}^{\mathrm{T}}$ contained meso-diaminopimelic acid as the diagnostic diamino acid in whole-cell hydrolysates. Galactose and ribose were the only sugars found in the hydrolysates [cell wall type III, according to Lechevalier \& Lechevalier (1980)]. The polar lipids comprised the diagnostic phospholipids phosphatidylcholine, diphosphatidylglycerol and phosphatidylethanolamine, as well as the non-diagnostic phosphatidylinositol, phosphatidylglycerol and unknown glycolipids (see Supplementary Fig. S2 in IJSEM Online). The phospholipid pattern was type III according to Lechevalier et al. (1977). The phospholipid patterns matched those found in other species of the Nocardiopsis (Kroppenstedt \& Evtushenko, 2002). The menaquinones of strain $\mathrm{HM}^{\mathrm{T}}$ were mainly of the MK-10 type: $\mathrm{MK}-10\left(\mathrm{H}_{2}\right), 35 \%$; MK-10 $\left(\mathrm{H}_{4}\right), 22 \%$; MK-10 $\left(\mathrm{H}_{0}\right)$, $19 \%$; MK- $9\left(\mathrm{H}_{2}\right), 18 \%$; and MK- $9\left(\mathrm{H}_{0}\right), 5 \%$. The fatty acid spectrum contained mainly saturated branched-chain acids: iso- $\mathrm{C}_{16: 0}(22.8 \%)$, anteiso- $\mathrm{C}_{17: 0}(19.2 \%)$, anteiso- $\mathrm{C}_{15: 0}$ (13.4\%), $\quad \mathrm{C}_{18: 0} \quad(8.8 \%), \quad 10$-methyl-C $\mathrm{C}_{18: 0} \quad(5.5 \%), \quad 10-$ methyl- $\mathrm{C}_{17: 0}(3.3 \%)$, cis-9- $\mathrm{C}_{18: 1}(3.3 \%)$, iso- $\mathrm{C}_{14: 0}(3.1 \%)$ and iso- $\mathrm{C}_{18: 0}(2.7 \%)$ (Table 2$)$. The fatty content was characteristic for members of the genus Nocardiopsis (Kroppenstedt, 1985, 1992). All chemotaxonomic properties of strain $\mathrm{HM} 7^{\mathrm{T}}$ were consistent with its classification within the genus Nocardiopsis (Kroppenstedt \& Evtushenko, 2002).

Chromosomal DNA was prepared using a DNA extraction kit (JetFlex). The 16S rRNA gene was enzymically amplified using the oligonucleotide primers $10-30 \mathrm{~F}$ ( $5^{\prime}$-GAGTTTGATCCTGGCTCA-3') and 1500R (5'-AGAAAGGAGGTGATCCAGCC-3'), as described by Rainey et al. (1996). PCR products were purified with a PCR product purification kit (Qiagen). 16S rRNA gene sequences of members of the

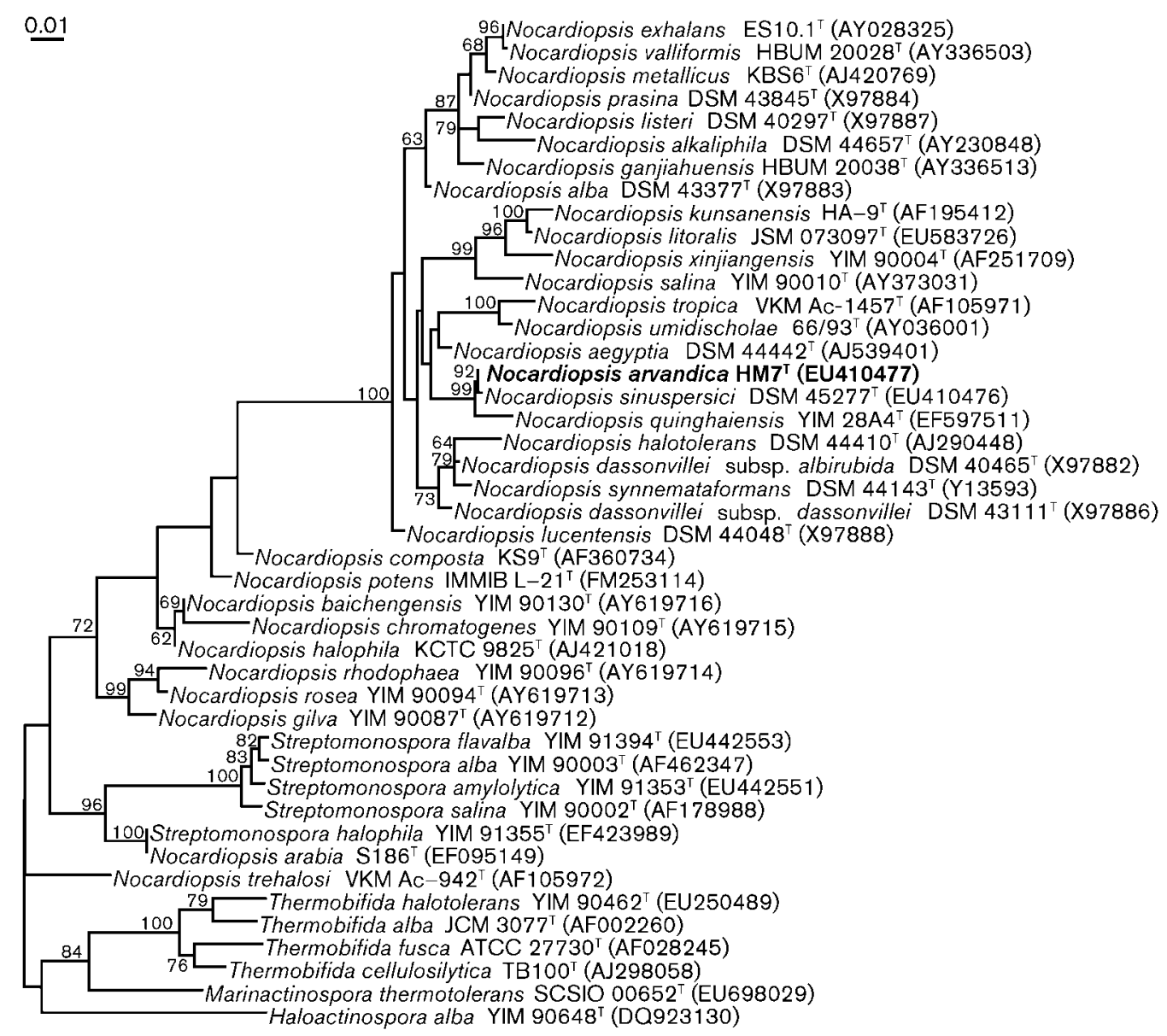

Fig. 1. Phylogenetic tree highlighting the position of strain $\mathrm{HM}^{\top}$ relative to all type strains of the family Nocardiopsaceae inferred from 1344 aligned characters (total alignment length was $1646 \mathrm{bp}$ ) of the $16 \mathrm{~S}$ rRNA gene sequence under the maximum-likelihood criterion. Rooting was done with the type strains of the genera Haloactinospora, Marinactinospora and Thermobifida. The branches are scaled in terms of the expected number of substitutions per site. Numbers above branches are support values from 1000 bootstrap replicates; only values greater than $60 \%$ are shown. 
Table 3. Characteristics that differentiate strain $\mathrm{HM} 7^{\top}$ from the most closely related Nocardiopsis species

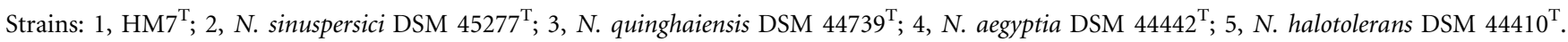
+, Positive; -, negative; -(+), weakly positive; ND, no data; DPG, diphosphatidylglycerol; PC, phosphatidylcholine; PE, phosphatidylethanolamine; PG, phosphatidylglycerol; PI, phosphatidylinositol; PME, phosphatidylmethylethanolamine.

\begin{tabular}{|c|c|c|c|c|c|}
\hline Characteristic & 1 & 2 & 3 & 4 & 5 \\
\hline \multicolumn{6}{|l|}{ Utilization of: } \\
\hline D-Galactose & + & + & - & + & + \\
\hline L-Arabinose & - & - & + & + & - \\
\hline Melibiose & + & + & - & + & + \\
\hline Adonitol & - & - & - & $\mathrm{ND}$ & - \\
\hline Glycerol & + & + & + & + & + \\
\hline Inositol & - & - & + & + & - \\
\hline Sucrose & - & + & + & + & + \\
\hline Ribose & + & - & - & - & - \\
\hline Lactose & - & + & - & $-(+)$ & - \\
\hline Mannitol & - & + & + & + & - \\
\hline D-Mannose & - & + & + & + & + \\
\hline L-Rhamnose & - & + & - & + & - \\
\hline D-Xylose & - & + & - & + & - \\
\hline Raffinose & - & - & - & - & - \\
\hline Gluconate & + & - & - & - & - \\
\hline Propionate & - & + & - & + & - \\
\hline Adenine & + & + & + & - & - \\
\hline Allantoin & + & - & + & + & - \\
\hline \multicolumn{6}{|l|}{ Growth at/in: } \\
\hline $10{ }^{\circ} \mathrm{C}$ & - & - & + & + & + \\
\hline $40{ }^{\circ} \mathrm{C}$ & + & - & - & - & - \\
\hline $5 \% \mathrm{NaCl}$ & + & + & + & - & + \\
\hline $10 \% \mathrm{NaCl}$ & + & + & + & - & + \\
\hline $15 \% \mathrm{NaCl}$ & + & + & - & - & + \\
\hline $20 \% \mathrm{NaCl}$ & - & - & - & - & - \\
\hline pH 12 & + & + & - & + & - \\
\hline Major menaquinones ${ }^{\star}$ & $\begin{array}{c}10 / 2,10 / 4,10 / 0 \\
9 / 2,9 / 0\end{array}$ & $\begin{array}{c}10 / 0,9 / 0,10 / 2 \\
9 / 2,10 / 4\end{array}$ & $\begin{array}{c}10,10 / 2,11 / 2 \\
11\end{array}$ & $10 / 6,10 / 8$ & $10 / 0,10 / 2$ \\
\hline Polar lipids & PI, PG, PC, PE, DPG & PG, PE, PC, PI & PC, PG, DPG & $\begin{array}{c}\text { PC, PME, PI, } \\
\text { PG, DPG }\end{array}$ & $\begin{array}{c}\text { PC, PI, PG, PME, } \\
\text { DPG }\end{array}$ \\
\hline
\end{tabular}

${ }^{\star}$ Nomenclature, e.g. 10/4, MK-10 $\left(\mathrm{H}_{4}\right)$.

family Nocardiopsaceae were aligned with POA v.2 (Lee et al., 2002) in progressive mode in conjunction with BLASTN (Altschul et al., 1990) and ambiguous regions were subsequently removed using Gblocks (Castresana, 2000) under default settings. Maximum-likelihood bootstrapping and a subsequent search for the best-known tree were conducted using RAxML v.7.04 (Stamatakis et al., 2008) with 1000 replicates of the novel fast bootstrap algorithm and GTR + GAMMA as the substitution model, approximated with GTR + CAT during the tree search (commandline switches $-\mathrm{fb}-\mathrm{m}$ GTRMIX). The tree was rooted with the Haloactinospora-Marinactinospora-Thermobifida clade included in the sample and is shown in Fig. 1. The DNA $\mathrm{G}+\mathrm{C}$ content of strain $\mathrm{HM}^{\mathrm{T}}$ was determined by HPLC (Mesbah et al. 1989; Tamaoka \& Komagata, 1984).

DNA for hybridization experiments was prepared using a French pressure cell (Thermo Spectronic) and was purified by chromatography on hydroxyapatite as described by Cashion et al. (1977). DNA-DNA hybridization was carried out as described by De Ley et al. (1970) with the modifications of Huß et al. (1983) using a model Cary 100 Bio UV/VIS-spectrophotometer equipped with a Peltierthermostatted $6 \times 6$ multicell changer and a temperature controller with an in situ temperature probe (Varian).

According to the aligned, almost complete 16S rRNA gene sequences, strain $\mathrm{HM}^{\mathrm{T}}$ was most similar to members of the genus Nocardiopsis, with the highest similarity to Nocardiopsis sinuspersici DSM $45277^{\mathrm{T}}$ (Hamedi et al., 2010) $(99.8 \%)$ and Nocardiopsis quinghaiensis YIM 28A4 ${ }^{\mathrm{T}}$ (Chen et al., 2008) (99.3\%); similar values were found for other species of the genus Nocardiopsis. When the phylogenetic position of strain $\mathrm{HM}^{\mathrm{T}}$ was investigated with all recognized species of the genus Nocardiopsis, the strain formed a monophyletic clade with $N$. sinuspersici DSM 
$45277^{\mathrm{T}}$ and $N$. quinghaiensis YIM $28 \mathrm{~A} 4^{\mathrm{T}}$ with $99 \%$ bootstrap support. Fig. 1 shows a phylogenetic dendrogram displaying the relatedness of strain $\mathrm{HM}^{\mathrm{T}}$ to type strains of the genus Nocardiopsis.

DNA-DNA hybridization studies showed that the DNADNA relatedness between strain $\mathrm{HM}^{\mathrm{T}}$ and $N$. sinuspersici DSM $45277^{\mathrm{T}}$ was $37.6 \%( \pm 1.1)$, whereas $N$. quinghaiensis DSM $44739^{\mathrm{T}}$ was related to these two strains by $39.6 \%$ $( \pm 0.2)\left(N\right.$. sinuspersici DSM $\left.45277^{\mathrm{T}}\right)$ and $38.9 \%( \pm 2.1)$ $\left(\mathrm{HM} 7^{\mathrm{T}}\right)$. The observed levels of DNA-DNA relatedness demonstrated the genomic distinctiveness of strain $\mathrm{HM} 7^{\mathrm{T}}$ when compared with $N$. sinuspersici DSM $45277^{\mathrm{T}}$ and N. quinghaiensis DSM $44739^{\mathrm{T}}$.

Strain $\mathrm{HM}^{\mathrm{T}}$ differed chemotaxonomically from its sister taxa N. sinuspersici DSM $45277^{\mathrm{T}}$ and N. quinghaiensis DSM $44739^{\mathrm{T}}$, thus enabling it to be clearly differentiated. These strains showed different fatty acid types (Table 2), predominant menaquinones and phospholipid patterns (Table 3). Strain $\mathrm{HM}^{\mathrm{T}}$ could be differentiated from $N$. sinuspersici DSM $45277^{\mathrm{T}}$ by means of phenotypic properties such as the consumption of a broad range of compounds including sucrose, ribose, lactose, mannitol, Dmannose, L-rhamnose, D-xylose, gluconate, propionate and allantoin. It could also be differentiated from $N$. quinghaiensis DSM $44739^{\mathrm{T}}$ by the consumption of D-galactose, L-arabinose, melibiose, inositol, sucrose, ribose, mannitol, D-mannose and gluconate (Table 3). Based on the above phenotypic and genotypic results, it is concluded that isolate $\mathrm{HM}^{\mathrm{T}}$ merits species status within the genus Nocardiopsis and the name Nocardiopsis arvandica sp. nov. is proposed for this isolate, with $\mathrm{HM}^{\mathrm{T}}$ (=UTMC $00103^{\mathrm{T}}=$ DSM $45278^{\mathrm{T}}=$ CCUG $\left.58831^{\mathrm{T}}\right)$ as the type strain.

\section{Description of Nocardiopsis arvandica sp. nov.}

Nocardiopsis arvandica (ar.van'di.ca. N.L. fem. adj. arvandica of or belonging to Arvand, referring to the geographical origin of the type strain, the Arvand River).

Aerobic, Gram-positive, non-acid-fast actinomycete that forms an extensively branched substrate mycelium and abundant aerial mycelium. Hyphae of the aerial mycelium are straight to flexuous. In older cultures, hyphae of aerial mycelium differentiate into rod-shaped, smooth-surfaced spores. Soluble pigments, including melanin, are not produced. A light brown substrate mycelium and a light brown aerial mycelium are produced on yeast extract-malt extract agar. Optimal growth occurs at $25-30{ }^{\circ} \mathrm{C}$. Good growth occurs in media containing $0-15 \% \mathrm{NaCl}$. Grows at pH 6-11. D-Galactose, melibiose, glycerol, ribose and gluconate are used as sole carbon sources, but not Larabinose, adonitol, inositol, sucrose, lactose, mannitol, Dmannose, D-xylose, L-rhamnose, raffinose or propionate. Utilizes L-alanine, L-asparagine, L-proline, L-serine, Larginine, L-tryptophan, cysteine, histidine, phenylalanine, lysine, ornithine and L-valine as the sole nitrogen sources. Decomposes allantoin and adenine. Whole cell hydrolysates contain meso-diaminopimelic acid, but no diagnostic sugars.
Polar lipids are phosphatidylcholine, phosphatidylethanolamine, phosphatidylinositol, phosphatidylglycerol and diphosphatidylglycerol. Menaquinones include MK$10\left(\mathrm{H}_{2}\right)$, MK-10 $\left(\mathrm{H}_{4}\right)$, MK-10 $\left(\mathrm{H}_{0}\right)$ and MK-9 $\left(\mathrm{H}_{2}\right)$. The predominant fatty acids in whole-cell methanolysates are iso- $\mathrm{C}_{16: 0}$ and anteiso- $\mathrm{C}_{17: 0}$.

The type strain is $\mathrm{HM}^{\mathrm{T}} \quad\left(=\mathrm{UTMC} \quad 00103^{\mathrm{T}}=\mathrm{DSM}\right.$ $45278^{\mathrm{T}}=$ CCUG $58831^{\mathrm{T}}$ ), isolated from a sandy soil from the banks of the Arvand River, Khoramshahr, Khuzestan, Iran. The DNA $\mathrm{G}+\mathrm{C}$ content of strain $\mathrm{HM}^{\mathrm{T}}$ is $71.5 \mathrm{~mol} \%$.

\section{Acknowledgements}

We would like to thank Evelyne Brambilla and Marlen Jando for technical assistance.

\section{References}

Altschul, S. F., Gish, W., Miller, W., Myers, E. W. \& Lipman, D. J. (1990). Basic local alignment search tool. J Mol Biol 215, 403410.

Cashion, P., Holder-Franklin, M. A., McCully, J. \& Franklin, M. (1977). A rapid method for the base ratio determination of bacterial DNA. Anal Biochem 81, 461-466.

Castresana, J. (2000). Selection of conserved blocks from multiple alignments for their use in phylogenetic analysis. Mol Biol Evol 17, $540-552$.

Chen, Y.-G., Cui, X.-L., Kroppenstedt, R. M., Stackebrandt, E., Wen, M.-L., Xu, L. H. \& Jiang, C. L. (2008). Nocardiopsis quinghaiensis sp. nov., isolated from saline soil in China. Int J Syst Evol Microbiol 58, 699-705.

Chun, J., Bae, K. S., Moon, E. Y., Jung, S. O., Lee, H. K. \& Kim, S. J. (2000). Nocardiopsis kunsanensis sp. nov., a moderately halophilic actinomycete isolated from a saltern. Int J Syst Evol Microbiol 50, 1909-1913.

De Ley, J., Cattoir, H. \& Reynaerts, A. (1970). The quantitative measurement of DNA hybridization from renaturation rates. Eur J Biochem 12, 133-142.

Evtushenko, L. I., Taran, V. V., Akimov, V. N., Kroppenstedt, R. M., Tiedje, J. M. \& Stackebrandt, E. (2000). Nocardiopsis tropica sp. nov., Nocardiopsis trehalosi sp. nov., nom. rev. and Nocardiopsis dassonvillei subsp. albirubida subsp. nov., comb. nov. Int J Syst Evol Microbiol 50, 73-81.

Galatenko, O. A. \& Terekhova, L. P. (1990). [Isolation of antibioticproducing Actinomycetes from soil samples exposed to UV light]. Antibiot Khimioter 35, 6-8.

Hamedi, J., Mohammadipanah, F., von Jan, M., Pötter, G., Schumann, P., Spröer, C., Klenk, H.-P. \& Kroppenstedt, R. M. (2010). Nocardiopsis sinuspersici sp. nov., isolated from sandy rhizospheric soil. Int J Syst Evol Microbiol 60, 2346-2352.

Hayakawa, M., Sadakata, T., Kajiura, T. \& Nonomura, H. (1991). New methods for the highly selective isolation of Micromonospora and Microbispora from soil. J Ferment Bioeng 72, 320-326.

Hayakawa, M., Otoguro, M., Takeuchi, T., Yamazaki, T. \& limura, Y. (2000). Application of a method incorporating differential centrifugation for selective isolation of motile actinomycetes in soil and plant litter. Antonie van Leeuwenhoek 78, 171-185. 
Huß, V. A. R., Festl, H. \& Schleifer, K. H. (1983). Studies on the spectrophotometric determination of DNA hybridization from renaturation rates. Syst Appl Microbiol 4, 184-192.

Kawato, N. \& Shinobu, R. (1959). Streptomyces herbaricolor sp. nov., supplement: a simple technique for microscopic observation. Mem Osaka Univ Lib Arts Educ B 8, 114-119.

Kelly, K. L. (1964). Inter-Society Color Council - National Bureau of Standards Color Name Charts Illustrated with Centroid Colors. Washington, DC: US Government Printing Office.

Kroppenstedt, R. M. (1982). Separation of bacterial menaquinones by HPLC using reverse phase (RP18) and a silver loaded ion exchanger as stationary phases. J Liq Chromatogr 5, 2359-2367.

Kroppenstedt, R. M. (1985). Fatty acid and menaquinone analysis of actinomycetes and related organisms. In Chemical Methods in Bacterial Systematics (Society for Applied Bacteriology Technical Series vol. 20), pp. 173-199. Edited by M. Goodfellow \& D. E. Minnikin. New York: Academic Press.

Kroppenstedt, R. M. (1992). The genus Nocardiopsis. In The Prokaryotes. A Handbook on the Biology of Bacteria: Ecophysiology, Isolation, Identification, Applications, 2nd edn, pp. 1139-1156. Edited by A. Balows, H. G. Trüper, W. Dworkin, W. Harder \& K. H. Schleifer. New York: Springer.

Kroppenstedt, R. M. \& Evtushenko, L. I. (2002). The Family Nocardiopsaceae. In The Prokaryotes: a Handbook on the Biology of Bacteria, 3rd edn, vol. 3, pp. 754-795. Edited by M. Dworkin, S. Falkow, E. Rosenberg, K.-H. Schleifer \& E. Stackebrandt. New York: Springer.

Lechevalier, M. P. \& Lechevalier, H. A. (1980). The chemotaxonomy of actinomycetes. In Actinomycete Taxonomy (Special Publication no. 6), pp. 227-291. Edited by A. Dietz \& D. W. Thayer. Fairfax, VA: Society for Industrial Microbiology.

Lechevalier, M. P., De Bièvre, C. \& Lechevalier, H. A. (1977). Chemotaxonomy of aerobic actinomycetes: phospholipid composition. Biochem Syst Ecol 5, 249-260.

Lee, C., Grasso, C. \& Sharlow, M. F. (2002). Multiple sequence alignment using partial order graphs. Bioinformatics 18, 452-464.

Mesbah, M., Premachandran, U. \& Whitman, W. (1989). Precise measurement of the $\mathrm{G}+\mathrm{C}$ content of deoxyribonucleic acid by highperformance liquid chromatography. Int J Syst Bact 39, 159-167.

Meyer, J. (1994). The Genus Nocardiopsis Meyer 1976. In Bergey's Manual of Determinative Bacteriology, 9th edn, pp. 2562-2568. Edited by J. G. Holt, N. R. Krieg, P. H. A. Sneath, J. T. Staley \& S. T. Williams. Baltimore: Williams \& Wilkins.
Mikami, Y., Miyashita, K. \& Arai, T. (1982). Diaminopimelic acid profiles of alkalophilic and alkaline-resistant strains of Actinomycetes. J Gen Microbiol 128, 1709-1712.

Minnikin, D. E., O’Donnell, A. G., Goodfellow, M., Alderson, G., Athalye, M., Schaal, K. \& Parlett, J. H. (1984). An integrated procedure for the extraction of bacterial isoprenoid quinones and polar lipids. J Microbiol Methods 2, 233-241.

Nolan, R. D. \& Cross, T. (1988). Isolation and screening of Actinomycetes. In Actinomycetes in Biotechnology, pp. 2-8. Edited by M. Goodfellow, S. T. Williams \& M. Mordarski. London: Academic Press.

Nonomura, H. \& Ohara, Y. (1969). Distribution of actinomycetes in soil. VI. A culture method effective for both preferential isolation and enumeration of Microbispora and Streptosporangium strains in soil. J Ferment Technol 47, 463-469.

Nonomura, H. \& Ohara, Y. (1971). Distribution of actinomycetes in soil. X. New genus and species of monosporic actinomycetes in soil. J Ferment Technol 49, 895-903.

Rainey, F. A., Ward-Rainey, N., Kroppenstedt, R. M. \& Stackebrandt, E. (1996). The genus Nocardiopsis represents a phylogenetically coherent taxon and a distinct actinomycete lineage: proposal of Nocardiopsaceae fam. nov. Int J Syst Bacteriol 46, 1088-1092.

Sasser, M. (1990). Identification of bacteria by gas chromatography of cellular fatty acids, MIDI Technical Note 101. Newark, DE: MIDI Inc.

Shirling, E. B. \& Gottlieb, D. (1966). Methods for characterization of Streptomyces species. Int J Syst Bacteriol 16, 313-340.

Stamatakis, A., Hoover, P. \& Rougemont, J. (2008). A rapid bootstrap algorithm for the RAxML Web servers. Syst Biol 57, 758771.

Staneck, J. L. \& Roberts, G. D. (1974). Simplified approach to identification of aerobic actinomycetes by thin-layer chromatography. Appl Microbiol 28, 226-231.

Tamaoka, J. \& Komagata, K. (1984). Determination of DNA base composition by reversed-phase high-performance liquid chromatography. FEMS Microbiol Lett 25, 125-128.

Williams, S. T., Goodfellow, M., Alderson, G., Wellington, E. M. H., Sneath, P. H. A. \& Sackin, M. J. (1983). Numerical classification of Streptomyces and related genera. J Gen Microbiol 129, 17431813.

Yassin, A. F., Galinski, E. A., Wohlfarth, A., Jahnke, K.-D., Schaal, K. P. \& Trüper, H. G. (1993). A new actinomycete species, Nocardiopsis lucentensis sp. nov. Int J Syst Bacteriol 43, 266-271. 